\title{
DELINEATION OF STRUCTURE ELEMENTS AND THE BASEMENT DEPTH AT THE JIFARA PLAIN NW LIBYA USING INTEGRATION APPLICATION OF POTENTIAL FIELD DATASET
}

\author{
Fouzie TREPIL ${ }^{1,3)}$, Sufian KAHOUL ${ }^{5)}$, Osagie Abel UYIMWEN ${ }^{4)}$, \\ Abdelhakim ESHANIBLI ${ }^{1,2)}$ *, Nur Azwin ISMAIL ${ }^{1)}$ and Hussin GHANOUSH ${ }^{2,3)}$ \\ 1) School of Physics, University of Science Malaysia, 11800, Pulau Penang, Malaysia \\ 2) Libyan Petroleum Institute, Tripoli, 6431, Libya \\ 3) Faculty of Science, University of Tripoli, Department of Geophysics, 13275, Tripoli, Libya \\ 4) University of Abuja, Abuja, Nigeria \\ 5) School of Chemical and Energy Engineering, University of Technology Malaysia, 81310, Johor, Malaysia \\ *Corresponding author's e-mail: abdelhakim1990h@gmail.com
}

\section{ARTICLE INFO}

Article history:

Received 15 November 2020

Accepted 9 February 2021

Available online 25 February 2021

\section{Keywords:}

Gravity

Magnetic

Gharyan

Jifara plain

Libya

\begin{abstract}
In this study, the analysis of ground gravity data (from the Libyan Petroleum Institute) and aeromagnetic data (from the African Magnetic Mapping Project) are used to delineate the structure elements and basement depth within the Jifara plain, northwest Libya. A high-pass filter and a reduction-to-the-pole (RTP) transformation are applied to the gravity and aeromagnetic data respectively. The Total horizontal gradient and Centre for Exploration Targeting (CET) grid analysis are applied to gravity datasets. Werner deconvolution is applied to the RTP magnetic data. One 2-D forward modelling profile is applied to gravity and magnetic dataset. The results show gravity anomaly highs and magnetic anomaly with different structure trends. Werner deconvolution profile shows a high-density intrusion (about $1.8 \mathrm{~km}$ from the surface) within the sedimentary sequence. The intrusion may be the result of the Eocene volcanic activities near the Gharyan region. The 2-D model shows that the basement depth of Jifara plain ranges from 2.8 to $3.0 \mathrm{~km}$. The integration results of the gravity and magnetic dataset reflect various periods of tectonic activities within Jifara plain and the adjacent area.
\end{abstract}

\section{INTRODUCTION}

Ambiguities associated with hydrocarbon detection can be reduced by combining both geological and geophysical methods of exploration. This combination can increase the propensity of delineating structural elements that control the accumulation of hydrocarbon in the Jifara plain located in northwest Libya (Thurmond et al., 2006). The area of study is located in the north-western part of Libya and is bounded by longitudes $12.40^{\circ} \mathrm{E}$ to $13.90^{\circ} \mathrm{E}$ and latitudes $31.80^{\circ} \mathrm{N}$ to $32.70^{\circ} \mathrm{N}$ (Fig. 1). According to the location of the study region that is located between two production basins which are the Ghadames basin at the south of the study area and Pelagian basin at the north offshore of the area, this makes the Jifara Plain promising area of potentials for hydrocarbon accumulation. More so the study region is regarded as a part of the Atlas fold belt that structurally complicated due to the different geological events that occurred within and around of the region of the study. Morphologically, the area is a large plain with no notable landforms. Different hypotheses have been put forward vis-à-vis the genesis and structural arrangements around the Jifara plain and its adjoining Jabal Nafusah (Lipparini, 1940; Zivanovic, 1977; Wilson and Guiraud 1992).
Previously, numerous investigations e.g., (Saadi et al., $2009,2010)$. have provided information within and around the Jifara plain but few published reports (based on the analysis of potential field data) focus on the Jifara plain and the surrounding area. Saadi et al. (2009) used an integrated approach to constrain the geological structure of the Jifara plain in northwest Libya from analysis of digital elevation model (DEM), Landsat ETM+ images, well logs, and magnetic data. The result of this work suggests that three main fault systems, trending northwest-southeast, east-west, and northeast-southwest control the Jifara plain. Saadi et al. (2010) applied an integrated analysis of remotely sensed data of the SRTM, Landsat ETM+ images as well as data from geology, well logs and potential field to investigate the structural and tectonic history of the Ghadames Basin in the west of Libya. The result indicated four main fault trends (WNW, NNW, NW and ENE) with the ENE lineaments being the oldest in the study area. During the year 2011-2012, most of the field works are stopped due to the instability and insecurity in Libya. The dataset used in this work are gathered before that period. Unfortunately, a representative structural model of the area is not available. Consequently, this study attempts to delineate the structural elements and the basement 


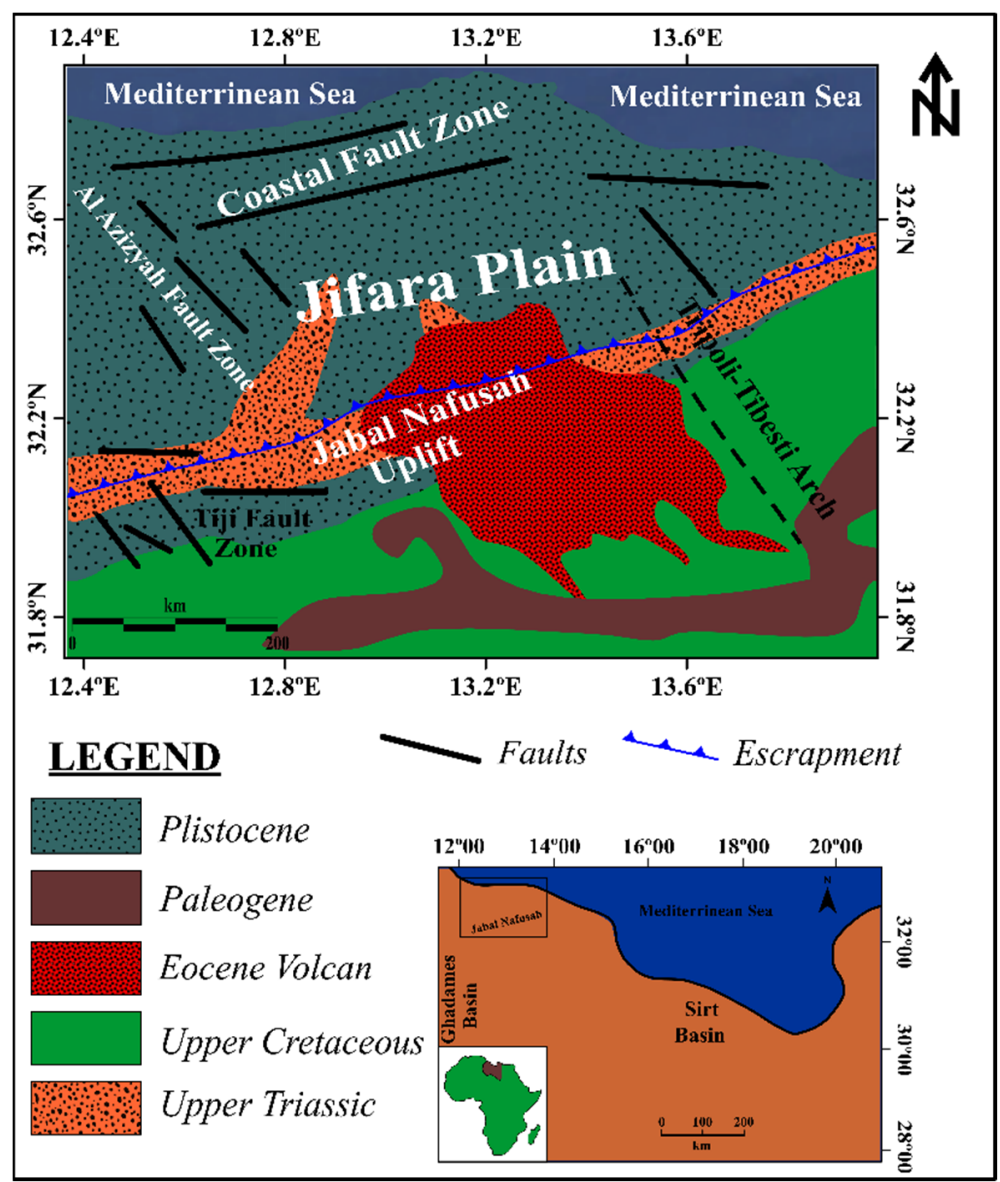

Fig. 1 Geological map of the study region and the Black rectangle in the small map identifies the total area covered by the dataset (modified after Zivanovic (1977)).

depth around the Jifara plain by the use of both magnetic and gravity data. The focus of the study will be on the structural distribution around the area.

\section{GEOLOGICAL SETTING}

The Jifara plain is an asymmetrical structure with gentle sloping towards the southern flank and a steeper sloping towards the northern flank (Hallett and ClarkLowes, 2017). The area is located at the intersection of two significant structural bodies: the Tripoli-Tibesti Arch Trend (TTAT) and the Jifara Arch Trend (JAT). The TTAT trends in the NNW direction and existed at the Caledonian times while the JAT existed because of Hercynian distortion trends in the East-West direction. (Goudarzi, 1980). The basement structure of the Jifara plain is controlled by Jifara flexure which is represented the Hercynian orogeny (Anketell and Ghellali, 1991). During the Triassic, subsidence of the Tripoli-Tibesti Arch created the environment for sedimentation that occurred afterwards (Hallett, 2002). The most conspicuous feature within the area is the Major Hercynian unconformity. In general, the area is consisting of Mesozoic limestone mixed with sandstone and shale overlain unconformably by Cenozoic deposits (Anketell and Ghellali, 1991). This feature cuts the Palaeozoic sequence and overlies the
Mesozoic sediments. The unconformity is the consequence of a collision between the Laurussia and the Gondwana continentals which resulted in both uplift and folding (Boote et al., 1998). A large escarpment formed along the E-W of the fault line of the Jifara plain and both Triassic and Jurassic rocks outcropped on the escarpment (Anketell and Ghellali, 1991). Extensive erosion was contributed to the removal of large amounts of Mesozoic sediments from the Jifara plain (Dercourt et al., 1986). The Nafusah uplift (Nafusah Arch) was a part of the Ghadames basin during the early Paleozoic and created a thick sequence of Paleozoic sediments (Abdunaser and McCaffrey, 2015). The Nafusah Uplift ("Nafusah Arch") (Fig.1), on the other hand, is an E-W and NE-SW trending eminent tectonic feature which refers to the border between the Jifara plain and Ghadames Basin to the north (Abohajar et al., 2009). In the late Permian-Middle Triassic, the relative movements between the African and the Eurasian plates produced geologic features that trend westwards (Van Der Meer and Cloetingh, 1993). Permian clastic sediments were widespread in the Jifara Plain and Tripolitania Basin (Del Ben and Finetti, 1991). Volcanic activities during the Cretaceous created volcanic rocks that covered the Upper Jurassic 


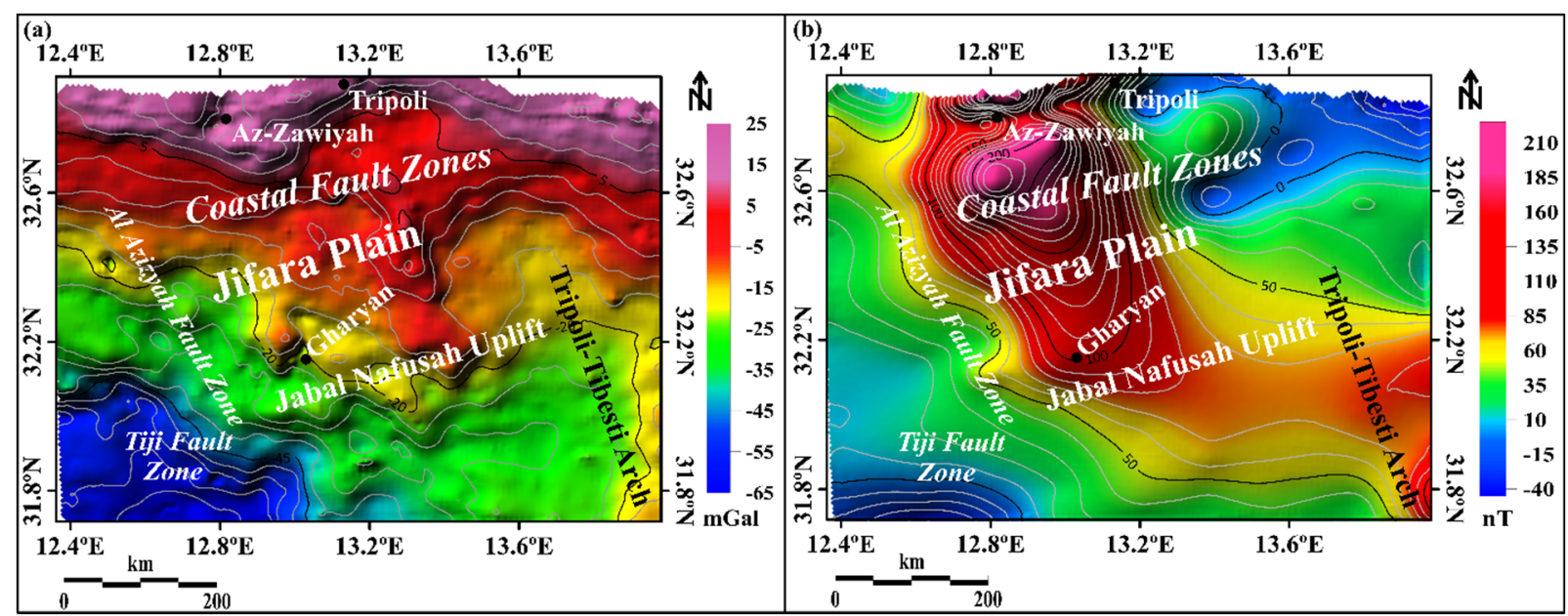

Fig. 2 Bouguer gravity anomaly with contour interval $15 \mathrm{mGal}$ in (a), Total Magnetic intensity map with contour interval $50 \mathrm{nT}$ in (b).

sediments (Hallett and Clark-Lowes, 2017). The volcanic rocks consist of three types: phonolite intrusions, basalt flows, and basalt cones (Antonovic, 1977). According to Anketell and Ghellali (1991), the Jifara plain and surrounding area are dominated by NW-SE, NNW-SSE, and E-W fault orientations in the Mesozoic sedimentary section. These faults resulted from strike-slip movements between the Jifara and south atlas. The tectonic activities during the Eocene contributed to the production of basaltic flows close to the Gharyan region (Abdunaser and McCaffrey, 2015). The subsidence that occurred during the Miocene created different sedimentary environments (Tawadros, 2001). During the late cretaceous regional extension movement affected the north Africa, which contributed to formation the basins in Libya such as Sirt basin (Abdunaser and McCaffrey, 2015).

The NW-SE and NNW-SSE normal faults that occurred during the late cretaceous are affected the north African margin and contributed to creating striking basins such as the Sirt basin (Baird et al., 1996). On the other hand, the NE-SW extension movement was strongly active in the east of the Sirt basin and offshore in the Tripoli Basin as well as the Pelagian sub-basin (Anketell, 1996).

\section{MATERIALS AND METHOD \\ 3.1. DATA}

Gravity land survey dataset for the Jifara plain was obtained from the Libyan Petroleum Institute (LPI) located in Tripoli, the capital of Libya. The Libyan Petroleum Institute has ties to the Libyan Gravity Project (LGP). The LGP obtains data from numerous oil and gas companies working in Libya and from the National Oil Corporation (NOC) (Saleem, 2015). The gravity data consists of 8,482 data-points taken at $1.0 \mathrm{~km}$ separation across the study area based on the Geodetic Reference System 1980 (GRS 80) at $2.67 \mathrm{~g} / \mathrm{cm}^{3}$ reduction density.
Aeromagnetic data is obtained from the African Magnetic Mapping Project (AMMP). The AMMP is part of a worldwide collaboration between Peterson, Grant and Watson Limited (PGW) located in Canada, while GETECH is located in the United Kingdom and The International Institute for Geo-Information Science and Earth Observation (ITC) is in the Netherlands. The AMMP collects all available airborne, ground, and marine magnetic data for the whole of Africa (Eshanibli et al., 2020). Flight lines and data-points along each line are both $1.0 \mathrm{~km}$ apart. A total of 89 flight lines in the N-S direction and roughly 95 data points along each flight line resulting in about 8,486 magnetic data-points.

\subsection{GRAVITY AND MAGNETIC DATA PROCESSING AND MODELLING}

The Bouguer gravity anomaly is the result obtained from applying all relevant corrections to the gravity dataset. Different gridding techniques exist within Oasis Montaj, (e.g., Bidirectional gridding, Minimum Curvature Random gridding, and Kriging). The gravity data for this study was taken randomly across the study area. The minimum curvature random gridding method is most appropriate for such kind of data points and as such the gridding method was applied to gravity data to get the Bouguer anomaly grid (Fig. 2a). However, the Bouguer gravity anomaly incorporates several anomalies with a broad amplitude spectrum. These anomalies are linked to the density variations in the subsurface rocks. On the other hand, the magnetic dataset is gridded by the Kriging method to get the Total Magnetic Intensity grid (TMI) (Fig. 2b), which is afterward reduced to the pole to get the Reduction to the Pole grid (RTP). The RTP transformation usually involves the assumption that the total magnetization of most rocks aligns parallel or anti-parallel to the Earth's main field ( Keller, 1986; Blakely, 1996). 


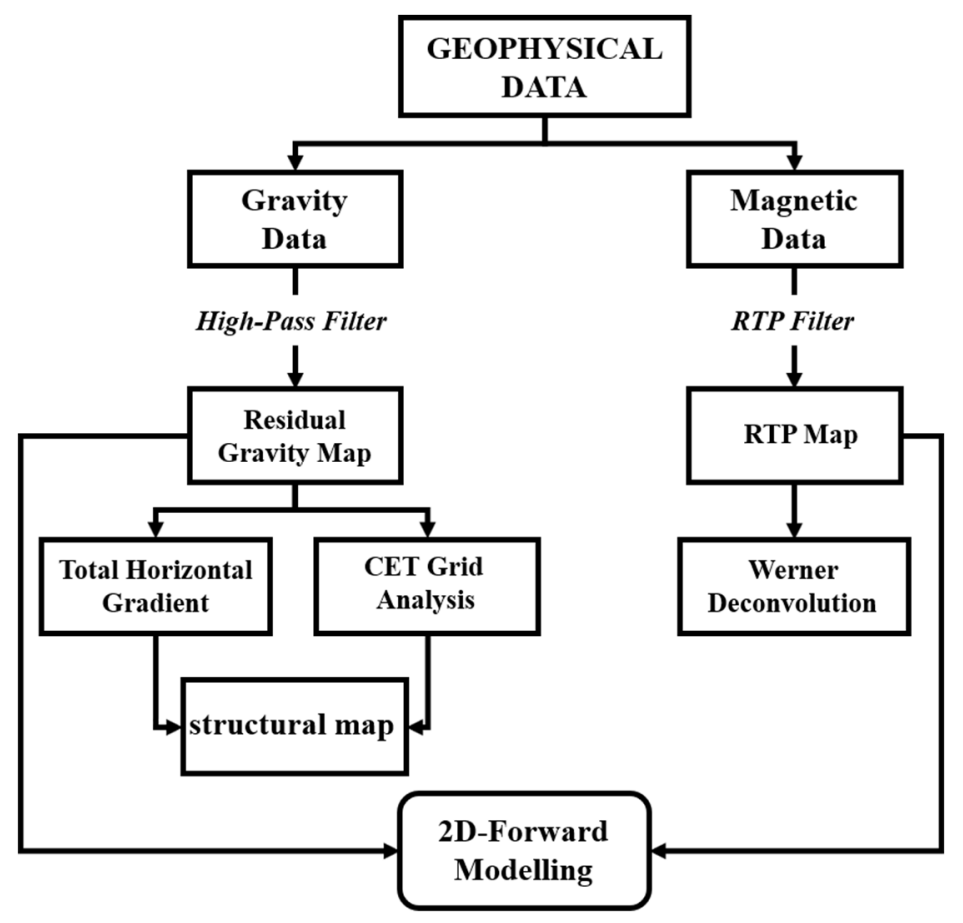

Fig. 3 A flow chart of the methodology.

The data processing involves the application of standard reduction algorithms to both gravity and magnetic dataset. The High pass filter, Total horizontal gradient, and CET grid analysis are applied to the ground gravity data while the reduction to the pole filter and Werner Deconvolution are applied to the magnetic data. Finally, the 2-D modelling technique is used to obtain a suitable model for the study area. A flow chart of the methodology is shown in Figure 3.

\section{- HIGH-PASS FILTER}

Bouguer gravity anomaly can be divided into two types: (i) Regional gravity anomaly and (ii) Residual gravity anomaly. Regional gravity anomaly is caused by deep sources and is characterized by low frequencies and long wavelengths (Subba Rao, 1996). Residual gravity anomaly is usually the consequence of the existence of shallow sources relatively characterized by high frequencies and short wavelengths (Subba Rao, 1996).

As a result, the high pass filter is useful to separate between regional and residual. This filter uses to pass or reject a range of wavenumbers from the data. The high-pass filter is selected, and the cut-off wavelength was changed between 5,10 , and $15 \mathrm{~km}$. The $10 \mathrm{~km}$ cut-off wavelength was chosen as the best cut-off wavelength that represents the regional effects needed to be removed.

\section{- TOTAL HORIZONTAL GRADIENT (THG) OF GRAVITY ANOMALY}

The Total Horizontal Gradient (Eq. 1) displays the borders of the gravity/magnetic irregularities utilizing upright contacts. The Horizontal Gradient filtering of the gravity anomalies is expected to enhance the visibility of the geological contacts within the study area. The horizontal gradient technique has been applied extensively to detect contacts of density variation from gravity and/or magnetic data (Cordell, 1979).

$\mathrm{HG}(x, y)=\sqrt{\left(\frac{\partial g}{\partial x}\right)^{2}+\left(\frac{\partial g}{\partial y}\right)^{2}}$

Where $\operatorname{HG}(x, y)$ is the magnitude of the horizontal gradient, $g$ is the gravity or magnetic anomaly, $\frac{\partial g}{\partial x}$ and $\frac{\partial g}{\partial y}$ are the partial derivatives of $g$ with respect to $x$ and $y$.

\section{- CET GRID ANALYSIS}

The group at the Centre for Exploration Targeting (CET) in Curtin University developed the CET Grid Analysis extension which is a set of algorithms that provides tools to enhance, locate and vectorize discontinuities with magnetic and gravity data. This allows fast and unbiased trend detection within the largest datasets. The algorithms developed by Holden et al. (2012) identifies the density discontinuity using a combination of texture analysis and bilateral symmetric feature detection. This study used the CET analysis for gravity data. The CET grid analysis equation is expressed in Equation 2:

$\mathrm{E}=-\sum_{\mathrm{i}=1}^{\mathrm{n}} P_{i} \log \rho_{i}$

Where the probability $\rho$ is obtained after normalizing the histogram of $n$ bins. 

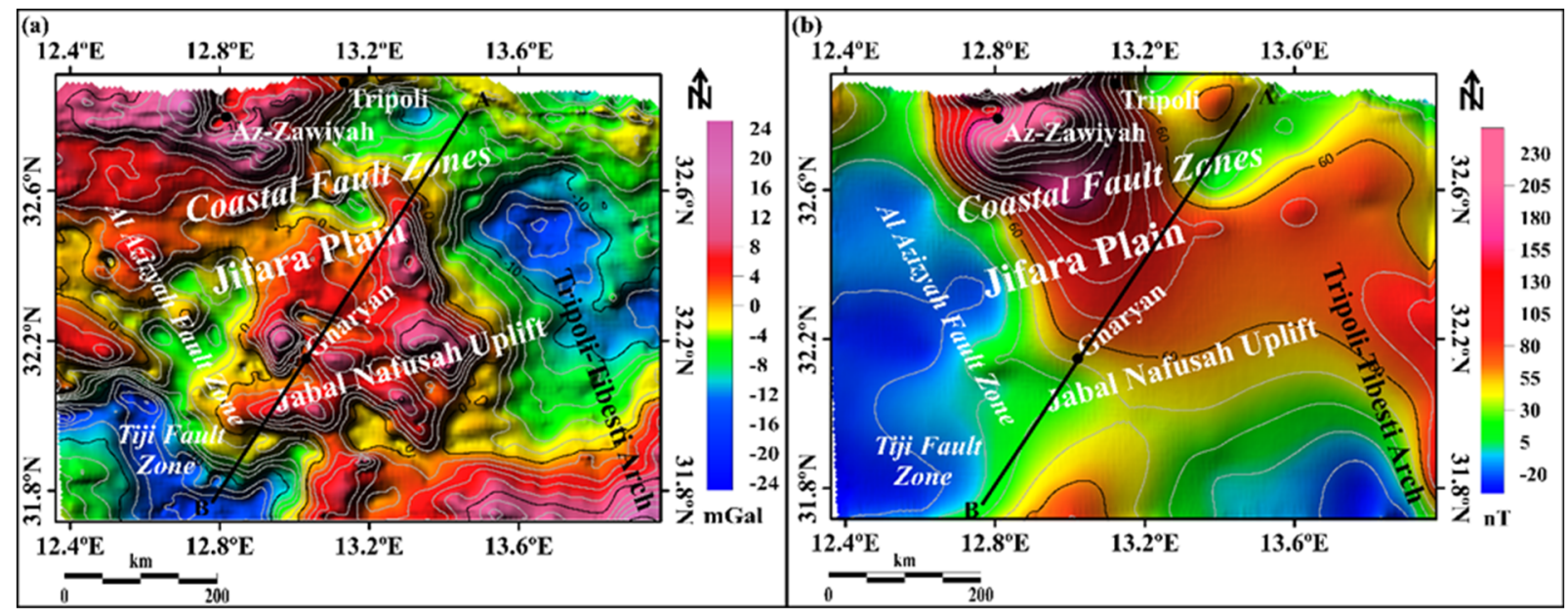

Fig. 4 Residual gravity anomaly map from High-Pass filter with $10 \mathrm{mGal}$ contour intervals in (a), Reduction to the pole map in (b). the black line(A-B) on both maps refer to the 2-D modelling profile.

\section{- WERNER DECONVOLUTION}

The standard Werner deconvolution method was developed by Werner (1953). This method aims to detect the geometry of the magnetic anomalies, depending on the identification of minor dykes and contacts with an unlimited trend and elongated depth, vertically on the measured profiles and regarded as magnetic anomaly sources. Werner deconvolution is expressed by Equation (3)

$\Delta \boldsymbol{T}(x)=\frac{A\left(x-x_{0}\right)+B_{Z}}{\left(x-x_{0}\right)+z^{2}}$

where $A$ and $B$ are field functions to be found, $x_{0}$ is the magnetic point location, $z$ is the measured depth, and $x$ is the position to be estimated from the magnetic anomaly.

\section{- 2-D MODELLING}

Qualitative interpretation of gravity and magnetic data just provides a general estimation of source parameters. More analysis is required to estimate the depth of the anomaly. 2-D forward modelling has been constructed to further study the effect of the basement on the gravity and magnetic data as well as imaging the basement rocks. The 2-D modelling of the study area has been defined using the GM-SYS Geosoft package (Popowski et al., 2006) and the model was defined by two layers (basement, sediments). The primary density information and susceptibility values were taken from previous studies such as ( Talwani et al., 1959; Essed, 1978), after that the density values was estimated by apparent density filter. This filter calculates the apparent density of the ground that would give rise to the observed gravity profile, the calculation process have been repeated several time to get the accurate values. The 2.67 density value of the basement has been estimated gravity measurements performed at different elevations on the area. As its known the basement density is homogeneous except the mineralised zone. The susceptibility values are estimated by Apparent
Susceptibility filter which is calculated the magnetic susceptibility of the magnetic source bodies using three assumptions:

1. The IGRF has been removed from the data.

2. There is no remanent magnetization.

3. All magnetic response is caused by a collection of vertical bodies of infinite depth and strike extent.

In addition to that three assumptions the main parameters such as the Reduction to the pole grid and suggested susceptibility values must be add during the calculation. This process should be repeated several times to gain the best and accurate susceptibility values for the $2 \mathrm{D}$ model profile.

\section{RESULTS AND DISCUSSION}

Residual gravity anomaly map (Fig. 4a) shows a range of $(24-25 \mathrm{mGal})$ in amplitude anomalies within and around Jifara plain. The dominant trend of the anomaly is in the NW-SE, E-W, and NE-SW orientations. The Jifara plain is characterized by a high positive anomaly (between 4.0 - $24 \mathrm{mGal}$ ). The northern part shows high positive anomaly regions trending E-W and NW-SE near Tripoli city and the Coastal fault zone. Jabal Nafusah uplift and adjacent such as Gharyan region are characterized by high positive anomaly ( $24 \mathrm{mGal})$. This high positive anomaly can be referring to the volcanic activities that occurred within this region during the Eocene period. To the south east of the Jifara plain is Tripoli-Tibesti Arch with anomalies between $(-12-4 \mathrm{mGal})$ at the northern part, and $(-4-8 \mathrm{mGal})$ at the southern part. Tiji Fault zone located southeast of Jifara plain shows NW-SE and E-W orientations.

Reduction to the pole (RTP) technique can isolate magnetic anomalous field areas. Magnetic anomalies are placed directly above the source in an RTP map. As expected, the aeromagnetic anomaly map (Fig. 4b). The angle of inclination $\left(45.0^{\circ} \mathrm{N}\right)$, declination $\left(1.50^{\circ} \mathrm{E}\right)$ of the field were taken at point $13.20^{\circ} \mathrm{N}$ and $30.40^{\circ} \mathrm{E}$, and the date of data collection 


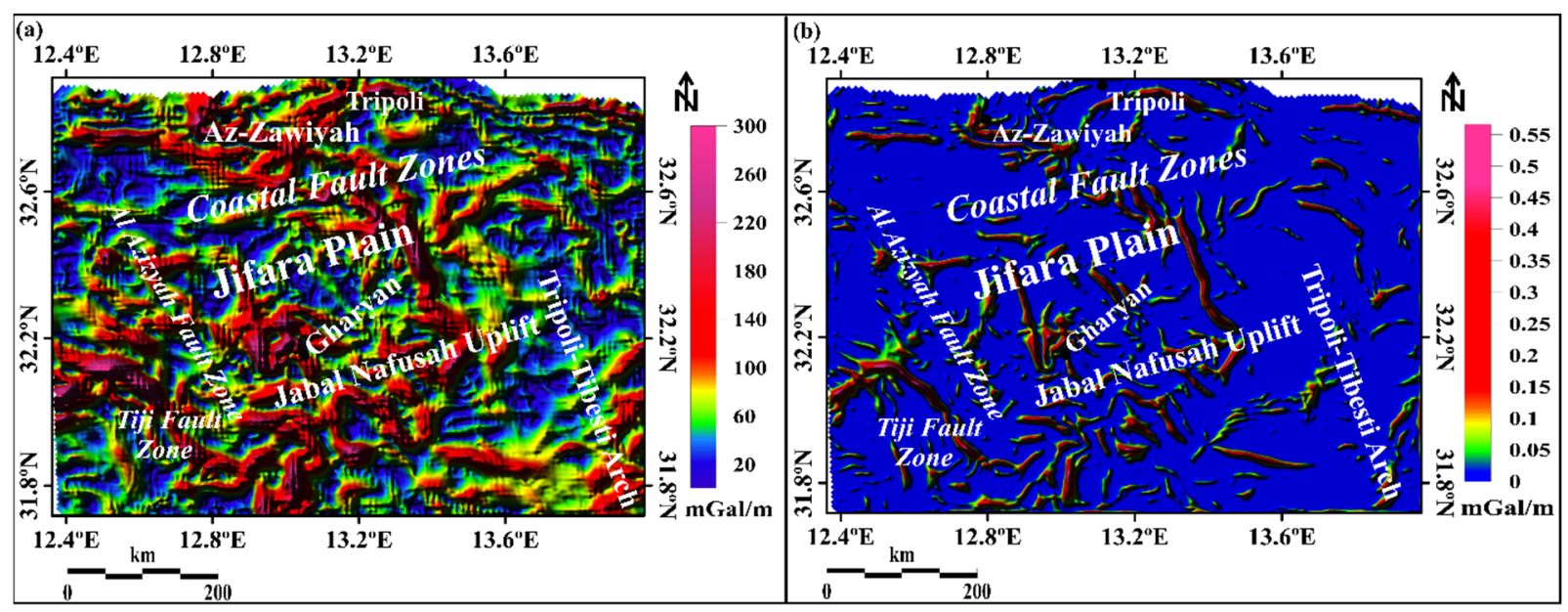

Fig. 5 Maps resulted from the application of Total Horizontal gradient in (a), and CET grid analysis in (b).

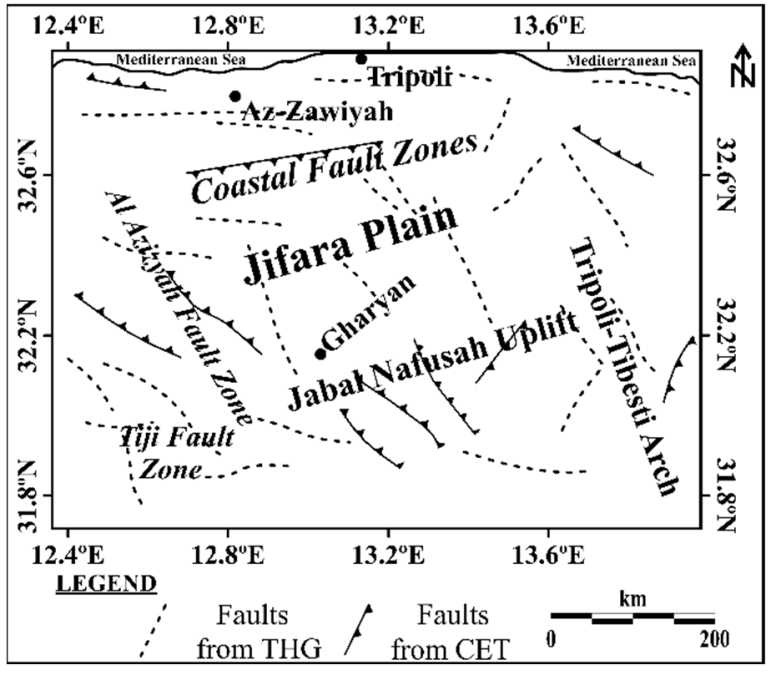

Fig. 6 Final structural map of the Jifara plain showing major faults.

which is in 1/06/1992. These parameters are very important to run the RTP filter within Oasis Montaj software. The inclination is the angle made by a compass needle when the compass is held in a vertical orientation, while the declination is the angle on the horizontal plane between magnetic north and true north. This angle varies depending on position on the Earth's surface and changes over time.

The RTP map shows an anomaly between $-20 \mathrm{nT}$ (nano Tesla) and above $230 \mathrm{nT}$ in different areas such as Jifara plain, coastal fault zone, and Tripoli city. The Al Aziziyah Fault Zone and Tiji fault zone are categorized by low anomaly values range from ( - $20 \mathrm{nT}$ to $30 \mathrm{nT}$ ). Jabal Nafusah uplift and TripoliTibesti Arch are characterized by high anomaly values NW-SE, NE-SW, and E-W trending truncated by strong NNW-SSE trending at Gharyan region and adjacent area.

Total horizontal gradient and CET grid analysis are performed on the gravity residual anomaly (Figs. 5a, b).

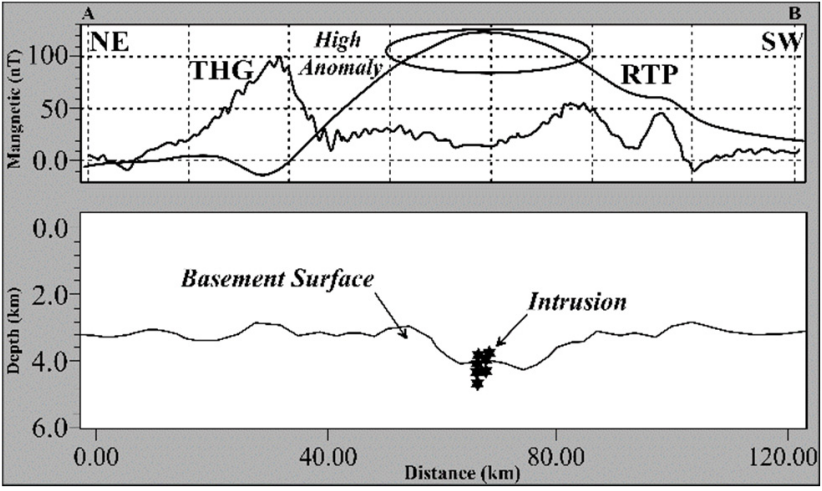

Fig. 7 Werner deconvolution solution along A-B showing the RTP curve and THG curve.

The result shows a strong NW-SE and NNW- SSE trending anomaly which are believed to be the result of crustal extensions that occurred in the late Cretaceous which are cut the Mesozoic sedimentary section. The E-W orientation results from strike-slip movements between the Jifara region and south atlas.

The final structural map (Fig. 6) of the Jifara plain and adjacent area shows different trend faults NW-SE, NNW-SSE, and E-W. The map is based on the dominant trends observed from THG and CET grid analysis. These faults represented different tectonic events such as the faults that occurred during the Late Cretaceous which resulted in crustal extension. The other NE-SW faults refer to the extension movement that affected east of Sirt basin, Pelagian, and Tripoli basin.

The result of applying the Werner Deconvolution profile (Fig. 7) appears to show a high positive magnetic anomaly (black oval) which coincides with the location of a high positive anomaly in the RTP map in (Fig. 4b). The causative body is estimated to be around $1.8 \mathrm{~km}$ below the surface. The existence of this body (dyke) may have been the result of volcanic activities that occurred during the Eocene time. 


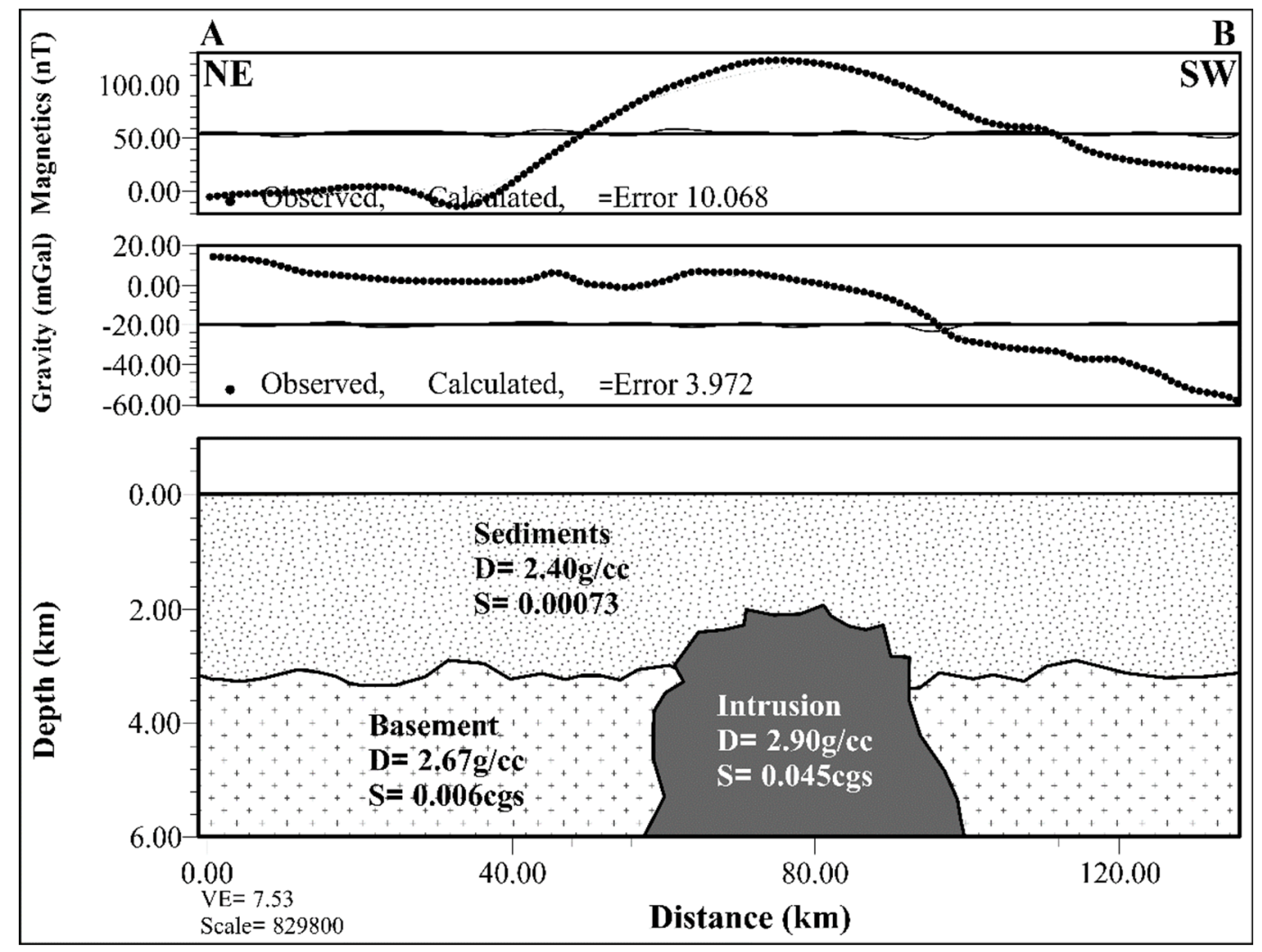

Fig. 8 NE-SW gravity and magnetic model profile A-B from the Jifara plain, the density values and susceptibility values estimated by density filter and susceptibility filter respectively (Talwani et al., 1959; Essed, 1978).

\section{CONCLUSION}

The result of applying the different enhancement techniques have been represented in different maps. The residual gravity anomaly map and the reduction to the pole map show different anomalies distributed within the study area. These varying anomalies are the result of different features with varying densities and magnetic susceptibilities. The gravity and magnetic maps indicate that the study area is marked with elongated gravity and magnetic maxima and minima trending NW-SE, NNW-SSE, NE-SW, and E-W showing a strong correlation with the different structural geology within the study region. The residual gravity anomaly map shows amplitude anomalies range between -24 and $24 \mathrm{mGal}$ within and around the Jifara plain. The reduction to the pole map shows a maximum anomaly above $230 \mathrm{nT}$ in different areas. The THG and CET grid analysis of residual gravity anomaly shows a strong NW-SE and NNW- SSE trending anomaly which are believed to be the result of crustal extensions that occurred in the late Cretaceous which are cut the Mesozoic sedimentary section, more so the E-W directions refer to the strikeslip movements between the Jifara region and south atlas. The result of the Werner deconvolution shows that the causative body is about $1.8 \mathrm{~km}$ in depth. The basement depth is corroborated by the result of 2-D modelling that ranges from 2.8 to $3.0 \mathrm{~km}$ within the
Jifara plain. The result obtained from the 2-D model shows igneous intrusions beneath the Jifara plain.

\section{ACKNOWLEDGEMENTS}

The authors thank the Management of Libyan Petroleum Institute and National Oil Corporation, Libya for making data available for use in this work. The facilities provided by Universiti Sains Malaysia was also helpful in this study. We wish to acknowledge the efforts of our reviewers who have helped to improve the standard of this paper.

\section{REFERENCES}

Abdunaser, K. and McCaffrey, K.: 2015, A new structural interpretation relating NW Libya to the Hun Graben, western Sirt Basin based on a new paleostress inversion. J. Earth Syst. Sci., 124, 8, 1745-1763. DOI: $10.1007 / \mathrm{s} 12040-015-0631-4$

Abohajar, A., Krooss, B.M., Harouda, M. and Littke, R.: 2009, Maturity and source-rock potential of Mesozoic and Palaeozoic sediments, Jifarah Basin, NW Libya. J. Pet. Geol., 32, 4, 327-341. DOI: $10.1111 /$ j.1747-5457.2009.00453.x

Anketell, J.: 1996, Structural history of the Sirte Basin and its relationship to the Sabratah Basin and Cyrenaican Platform, northern Libya. In: M.J. Salem, M.T. Busrewil, A.A. Misallati, and M.A. Sola (eds), The Geology of the Sirte Basin. Elsevier, Netherlands, 5789. 
Anketell, J. and Ghellali, S.: 1991, A palaeogeologic map of the pre-Tertiary surface in the region of the Jifarah Plain and its implication to the structural history of Northern Libya. Paper presented at the Symposium on The Geology of Libya, 2381-2406.

Antonovic, A.: 1977, Geological Map of Libya, Explanatory Booklet, Sheet Mizdah NH 33-1. Industrial Research Center, Tripoli, Libya.

Baird, D.W., Aburawi, R.M. and Bailey, N.J. L.: 1996, Geohistory and petroleum in the Central Sirt Basin. The Geology of Sirt Basin, 3, 3-56.

Blakely, R.J.: 1996, Potential theory in gravity and magnetic applications,34. Cambridge University Press, New York, 441 pp. DOI:10.1017/CBO9780511549816

Boote, D.R.D., Clark-Lowes, D.D. and Traut, M.W.: 1998, Palaeozoic petroleum systems of North Africa. Geological Society, London, Special Publications, 132, 1, 7-68. DOI: 10.1144/GSL.SP.1998.132.01.02

Cordell, L.: 1979, Gravimetric expression of graben faulting in Santa Fe Country and the Espanola Basin. Paper presented at the New Mexico Geological Society. Guidebook, 30 Field Conference, New Mexico, 1979.

Del Ben, A. and Finetti, I.: 1991, Geophysical study of the Sirt rise. Paper Presented at The Third Symposium on the Geology of Libya, 2417-2431.

Dercourt, J., Zonenshain, L., Ricou, L.E., Kazmin, V., Le Pichon, X., Knipper, A. and Lepvrier, C.: 1986, Geological evolution of the Tethys belt from the Atlantic to the Pamirs since the Lias. Tectonophysics, 123, 1-4, 241-315. DOI: $10.1016 / 0040-1951(86) 90199-X$

Eshanibli, A., Khalil, A., Younis, A. and Ghanoush, H.: 2020, Structural framework of the Zelten Platform, South Sirte Basin, Libya using potential fields modelling. Acta Geodyn. Geomater., 17, 2, 229-236. DOI: 10.13168/AGG.2020.0017

Essed, A.S.: 1978, A reconnaissance Bouguer gravity map of Libya. M.Sc. Dissertation, Purdue University.

Goudarzi, G.H.: 1980, Structure - Libya. In: Salem, N.J., Busrewil, M.T. (Eds.), Geology of Libya. Al-Fateh Univ, Tripoli, 879-892.

Hallett, D.: 2002, Petroleum geology of Libya, $1^{\text {st }}$ edition. Elsevier. Amsterdam, The Netherlands.

Hallett, D. and Clark-Lowes, D.: 2017, Petroleum geology of Libya. Elsevier, Amsterdam, The Netherlands.

Holden, E.-J., Wong, J.C., Kovesi, P., Wedge, D., Dentith, M. and Bagas, L.: 2012, Identifying structural complexity in aeromagnetic data: An image analysis approach to greenfields gold exploration. Ore Geol. Rev., 46, 47-59.

DOI: $10.1016 /$ j.oregeorev.2011.11.002

Keller, G.V.: 1986, An introduction to geophysical exploration. EOS Trans. AGU, 67, 11, 132-132. DOI: 10.1029/EO067i011p00132-01
Lipparini, T.: 1940, Tettonica e geomorfologia della Tripolitania. Boll. Soc. Geol. Ital., 59, 33-45.

Popowski, T., Connard, G., Tull, S. and Bashilov, V.: 2006, GMSYS -3D gravity and magnetic modeling for OasisMontaj-User Guide. Northwest Geophysical Associates, 8, 3, 2-32.

Saadi, N.M., Aboud, E. and Watanabe, K.: 2009, Integration of DEM, ETM+, geologic, and magnetic data for geological investigations in the Jifara Plain, Libya. IEEE Trans. Geosci. Remote Sens., 47, 10, 33893398. DOI: 10.1109/TGRS.2009.2020911

Saadi, N.M., Zaher, M.A., El-Baz, F. and Watanabe, K. 2010, Integrated remote sensing data utilization for investigating structural and tectonic history of the Ghadames Basin, Libya. Int. J. Appl. Earth Obs. Geoinf., 13, 5, 778-791.

DOI: $10.1016 /$ j.jag.2011.05.016

Saleem, M.A.A.: 2015, Tectonic evolution and structural analysis of south-western Sirte Basin, Central Libya. Ph.D Dissertation, University of Birmingham, UK.

Subba Rao, D.V.: 1996, Resolving Bouguer anomalies in continents-a new approach. Geophys. Res. Lett., 23, 24, 3543-3546. DOI: 10.1029/96GL03471

Talwani, M., Worzel, J.L. and Landisman, M.: 1959, Rapid gravity computations for two-dimensional bodies with application to the Mendocino submarine fracture zone. J. Geophys. Res., 64, 1, 49-59. DOI: $10.1029 / J Z 0641001$ p00049

Tawadros, E.E.: 2001, Geology of Egypt and Libya Rotterdam, The Netherlands, A.A. Balkema, 468 pp. DOI: $10.1017 / \mathrm{S} 0016756803308027$

Thurmond, A.K., Abdelsalam, M.G. and Thurmond, J.B.: 2006, Optical-radar-DEM remote sensing data integration for geological mapping in the Afar Depression, Ethiopia. J. Afr. Earth Sci., 44, 2, 119134. DOI: $10.1016 /$ j.jafrearsci.2005.10.006

Van Der Meer, F.C. and Cloetingh, S.: 1993, Intraplate stresses and the subsidence history of the Sirt Basin, Libya. Tectonophysics, 226, 1-4, 37-58. DOI:10.1016/0040951(93)90109-W

Werner, S.: 1953, Interpretation of magnetic anomalies at sheet-like bodies. Sveriges Geologiska Undersok. Series C, Arsbok, 43, 6.

Wilson, M. and Guiraud, R.: 1992, Magmatism and rifting in Western and Central Africa, from Late Jurassic to recent times. Tectonophysics, 213, 1-2, 203-225. DOI: 10.1016/0040-1951(92)90259-9

Zivanovic, M.: 1977, Geological Map of Libya. Explanatory Booklet, Sheet Bani Walid NH 33-2. Industrial Research Center, Tripoli, Libya. 